\title{
Estimating the effects of financial access on poor farmers in rural northern Nigeria
}

Terfa W. Abraham

Correspondence:

Lorenzcurve@yahoo.com

National Institute for Legislative and

Democratic Studies (NILDS), No 1

River Niger Street, Maitama, Abuja,

Nigeria

\begin{abstract}
By recognizing the gap in the literature in examining the effects of financial resources and development outcomes at the household level, this paper examines whether the poorest income quintile would benefit most from programs aimed at increasing their access to financial services in rural northern Nigeria. Most households from this part of the world consist of farmers and, hence, are exposed to the vagaries of climate change. The data from 320 questionnaires administered in two rural communities (Rijau and Fakai) were analyzed using an ordered logit regression model. The results showed that access to financial services by using formal financial institutions and farmer savings clubs benefits vulnerable farmers (mostly women). The robustness check using the Brant test also confirmed that the parallel regression assumption of the model was not violated. A policy scenario that seeks to increase the delivery of financial services to rural farm households using community savings clubs and microfinance institution reforms for reaching the financially underserved was also found to benefit the poorest income quintile, hence, bringing them out of poverty.
\end{abstract}

Keywords: Rural households, Farm income, Climate change, Financial inclusion

\section{Introduction}

The vulnerability of farmers in Sub Saharan Africa to the adverse effects of climate change has been recognized by several studies (IPCC 2007, 2012, Boko et al. 2007, World Bank 2008, 2012). The financial innovations aimed at increasing the access of farmers to financial services as an adaptive strategy have been identified by several studies (see Siegel and Alwang 2005, Schneider and Gugerty 2011, Sanfo and Gérard 2012, World Bank 2012). However, the empirical evidence examining whether the various financial services benefit mostly poor and financially excluded farmers remains scarce. The agriculture in West Africa is largely rain-fed, hence, vulnerable to flood and drought. With over $70 \%$ of the West African population depending on agriculture, weather shocks severely affect rural livelihood (MeheRette 2009). Although climate risk management strategies are useful for minimizing risk and taming vulnerabilities (Vargas-Hill and Torrero 2009), financial markets (both insurance and credit markets) in West Africa are often underdeveloped, with over $80 \%$ of the population being financially excluded. According to Adesina (2012), despite accounting for $44 \%$ of the GDP, the agricultural sector only receives $2 \%$ of the total loans by commercial banks in Nigeria. Unfortunately, the high demands for collateral by banks, lack of capacity to develop appropriate credit instruments for agriculture, high perceived risks of lending

(c) The Author(s). 2018 Open Access This article is distributed under the terms of the Creative Commons Attribution 4.0 International License (http://creativecommons.org/licenses/by/4.0/), which permits unrestricted use, distribution, and reproduction in any medium, provided you give appropriate credit to the original author(s) and the source, provide a link to the Creative Commons license, and indicate if changes were made. 
to this sector, and general aversion of banks toward agriculture have led to the under-capitalization of the agricultural sector.

According to the Central Bank of Nigeria (CBN 2016), the Nigerian financial sector has recorded significant levels of growth and reorganization. However, a vital area in which banks continue to seek better results is providing access to financial services and thereby bridging the gap that constrains the growth of the agricultural sector. As of December 31, 2016, CBN (2016) documented that the financial sector in Nigeria comprised 26 banks, namely 21 commercial banks, four merchant banks, and one non-interest bank; one discount house; 987 microfinance banks, 66 finance companies; 35 primary mortgage banks; one mortgage refinancing company; and six development finance institutions. The total assets, deposits, and loan/advances of the commercial banks were 32 trillion, 18 trillion, and 15 trillion naira, respectively, while those of the microfinance banks as of December 31, 2016 were 326 billion, 149 billion, and 178 billion naira, respectively. However, despite the growth of the financial sector, which is a major driver of financial inclusion, in Nigeria, 41.6\% of the population is still financially excluded, according to a 2016 survey by Enhancing Financial Innovation and Access (EFInA). Nevertheless, Nigeria is one of the countries that committed to the Maya Declaration in 2011 as such, increasing the level of financial inclusion remains important if the country must attain the sustainable development goal of eradicating poverty for all.

Over time, recognizing the need to deliver greater access to financial services to farmers, several initiatives have been implemented in Nigeria. A review conducted by the World Bank (2008) on Nigeria's rural finance summarizes that Nigeria's history with rural finance provides lessons about the elements of past interventions that have worked and those that have not. The report notes that, on the positive side, Nigeria's rural finance policies and practices achieved some level of penetration by creating a rural branch network. Nigeria's experience using public private partnership arrangements between commercial banks and other private sector actors has also helped lower the risk and transaction costs. In terms of the negative legacies, the most important one is perhaps the culture of non-repayment among some borrowers, which has been fostered by poor repayment methodologies and subsidized interest rates, charged as part of the government agricultural finance initiatives. The following factors were identified to have hindered the expected impact of the efforts to enhance access to financial services in Nigeria: (i) inconsistency of government policies in rural finance; (ii) the financial illiteracy of many rural actors, exacerbating the problem; (iii) the methodology of "credit only" financial service initiatives, which paid insufficient attention to loan applications and omitted a large-and equally important-unmet demand for savings and other financial services; and (iv) the legacy of financial unsustainability and operational inefficiency of most government (and many non-governmental) rural finance institutions and programs.

Among the various adaptation strategies considered to mitigate the adverse effects of climate change on the poor, whether the initiatives aimed at increasing the access of households to financial services would also enhance their adaptive capacity and help bring them out of poverty is not clearly established. This reasoning is rooted in the typical agricultural household model (see Siegel and Alwang 2005; Schneider and Gugerty 2011; Sanfo and Gérard 2012) and the monotonicity axiom of robust poverty measures (see Ravallion and Chen 2001; Haughton and Khandker 2009), which suggests that, in 
situations where poor rural households are farmers (producers) as well as consumers, any income gain would reduce poverty. Therefore, the objectives of this study are: (1) to examine the effect of financial inclusive strategies on rural farm households distributed along income quintiles and (2) to determine whether the poorest income quintile would benefit the most from innovative strategies that are aimed at increasing the access to financial services as a climate change adaptation measure.

The general finding from the paper is that, whereas financial inclusive services have the potency to raise farmers out of poverty and provide them with access to funds towards implementing welfare enhancing innovations, those in the poorest income quintile - who are most females, benefit the least from such services. By organizing themselves into savings clubs, however, they stand a better chance of having access to finance. The policy implication is that financial services and government programmes targeted at enhancing the livelihood of rural farmers do not have homogenous effect on farmers across income quintile. As such, reforms aimed at providing the enabling environment for microfinance institutions to refocus their product/services to farmers in the poorest group, would be desirable. The paper is structured into five sections. Presented in the next section is the review of related literature while the analytical framework is discussed in section three. The discussion of results is the focus of section four. Lastly, the conclusion and recommendation are presented in the conclusion and recommendations section.

\section{Literature review}

\section{Review of agricultural finance initiatives in Nigeria}

Access to financial services is key to rural development (see Akinlo 2014) as it increases incomes through productive investment, helps create employment opportunities, facilitates investments in health and education, and reduces the vulnerability of the poor by helping them smooth their income pattern over time. Further, a lack of rural access to financial services not only retards rural economic growth, but also increases poverty and inequality. While Nigeria's own long history with rural finance shows a clear appreciation of the importance of rural financial access, the persistent absence of such sustainable access yields important lessons for the future. According to a report by the World Bank (2008), rural areas are home to $53 \%$ of Nigeria's population and more than $70 \%$ of its poor-mostly farmers. While it is well understood in Nigeria that the financial exclusion of the rural population stunts development, fewer than $2 \%$ of rural households have access to any type of institutional finance.

There had been a number of policy measures and programs over the past three decades that involve the reconstruction or reformation of the entire structure of the agricultural sector by creating appropriate institutions and public services designed to strengthen the economic position of farming and farm output. One such example is the National Accelerated Food Production Project. This program was established in 1973 to induce farmers to boost food production within the shortest possible time. Its main objectives were to accelerate the production of six major food crops, namely rice, millet, sorghum, maize, wheat, and cassava. The program had three components: research, extension, and agroservices (Anyanwu 1997). The inclusion of the research component was a clear indication on the role of research to increase output. Agricultural institutes, research centers, and research institutions coordinated the program 
and took charge of specific crops to achieve the aims of the program. Inadequate finance, inadequate commitment, and poor infrastructure were some of the factors that affected the program.

The River Basin Development Authorities (RBDAs) are another example. The development of river basins was conceived in 1963 with involvement in the Lake Chad Basin and River Niger Commissions by countries bordering the Chad Lake and the Niger River. The concept, according to Anyanwu (1997), was first tried in 1973 with the establishment of the Sokoto-Rima and Chad Basin development authorities. A number of river basins were subsequently introduced. By June 1984, the number of river basins totaled 18 across the nation. The RBDAs were expected to cater to the development of land and water resources for agricultural purposes and, generally, for rural development. Regarding water resources for agriculture, ground water resources were also exploited. The RBDAs assisted farmers to plant hectares of various crops in the area of irrigation. However, an inadequate workforce and the lack of financial and material resources hampered the activities of RBDAs.

The Operation Feed the Nation scheme was introduced mainly to increase food production and self-sufficiency in terms of food supply. Under this scheme, encouragement and material assistance were given to people in the form of technical advice and supply of essential farm inputs such as improved seeds, fertilizer, pesticides, farm implements, livestock, and livestock feed at subsidized prices (Anyanwu 1997).

The Green Revolution Programme was launched in 1980 to address the problem of food shortages and diversify the nation's sources of foreign exchange. To this end, all known constraints to increase production were removed. Under the scheme, new input procurement and distribution systems came into operation. Input subsidies and crop pricing policies were also streamlined along with the construction of rural physical infrastructures.

Agricultural Development Projects (ADPs) started in 1974 in northern Nigeria. The development approach focused on simple, improved packages for some of the major food crops, such as maize sorghum and millet. It also aimed at improving input supply systems, rural road networks, and village water supplies. The need and pressure to enlarge the program and cover all states led to the first multi-state (MSADP-I) and later to MSADP-II. The various components of ADPs are: farm and crop development, civil work/infrastructural development, institutional support and training, and technical assistance through short and long-term consultancies. The components listed above are important to increase food production.

Recent efforts in scaling up access to finance services are promoted under the CBN's Anchor Borrowers Programme and the government's Economic Recovery and Growth Programme (ERGP). According to the CBN Anchor Borrowers' Programme Guidelines (2016), the program, which was launched on November 17, 2015, is intended to create a linkage between the anchor companies involved in processing and smallholder farmers (SHFs) for key agricultural commodities. Its thrust is to provide farm inputs in kind and cash (for farm labor) to SHFs to boost the production of these commodities, stabilize input supply to agroprocessors, and address the country's negative balance of payments on food. At harvest, the SHF supplies his/her produce to the agroprocessor (anchor), who pays the cash equivalent to the farmer's account. ERGP is a short term policy document of the document that spans 2017-2020. It is meant to fast-track Nigeria's recovery from 
the recession it went into in 2016. It also identifies six sectors, including the agricultural sector, that would sustain Nigeria's economic growth (see NILDS and PASGR 2018). However, concerns have been generated on the consistency of the ERGP with existing agricultural policy frameworks, such the Agricultural Promotion Policy.

\section{Empirical literature}

According to a report by G20 (2011), over 2 billion adults globally lack access to basic financial services and more than $70 \%$ of the small and medium enterprises (SMEs) in developing economies lack access to credit. The Maya Declaration (to which Nigeria committed in 2011, with Ghana and Senegal joining in 2012), "recognizes the critical importance of financial inclusion to empowering and transforming the lives of all our people, especially the poor, its role in improving national and global financial stability and integrity and its essential contribution to strong and inclusive growth in developing and emerging market countries" (see MAYA Declaration Progress Report 2017: 30). By enhancing national and global financial stability and integrity, it also contributes to achieving strong and inclusive growth, which will help vulnerable households cope with the impact of climate change. Moreover, member countries are committed to putting in place policies that will enhance financial inclusion to create an enabling environment for cost-effective access to financial services that makes full use of the appropriate innovative technology and substantially lowers the unit cost of financial services. These services could include facilitating credit transfers and their receipt through mobile devices. Several studies and reports have argued that climate change could have potentially grave consequences for the well-being and security of people worldwide and have called for an integrated approach of addressing the challenges posed by climate change.

For instance, Sanfo and Gérard (2012) examined the effects of a set of public policy options (including access to credit) on breaking the vicious circle of the poverty trap for the poor in rural areas of Burkina Faso using dynamic household and mathematical programming models. They found that the public policies aimed at increasing the availability of irrigation water, lowering marketing costs, increasing access to credit, reducing price variability, and increasing resilience through access to animal traction for instance were beneficial to all farmers in the study area. Additionally, policies focusing on increasing access to equipment were of significant benefit to the poorest. Although increasing access to finance can be used to increase the availability of irrigation water and build resilience through access to animal traction, their paper did not identify the transmission mechanism through which such access to finance leads to poverty reduction. Thus, while the conclusion that combining all existing policy measures would help the poorest group cross the poverty line is important, the study did not recognize trade-offs in policy of the economic impossibility of implementing all options, as governments may be more interested in implementing just one or two at a time.

Forcella (2013) argued that the proximity of MFIs to the clients could provide a comparative advantage to support local adaptation strategies. Additionally, through microfinance, vulnerable groups can increase their resilience from assets accumulation and diversification of income sources. While this channel of diversification is feasible for developed economies and farmers in urban centers, the author completely ignored the separability characteristic of a typical farm household, where farmers are both 
consumers and producers. Other transmission channels through which microfinance can help households adapt is through the provision of non-productive loans, remittances, and information sharing. The link with remittances is also consistent in Fonta et al. (2011), who argued that household poverty reduces faster with remittances than without them in Nigeria. Forcella (2013) also identified trade-offs that could be associated with microfinance and climate change adaptation strategies. However, these tradeoffs (e.g., microfinance being short term and climate change requiring long-term adaptation) did not contextualize the role microfinance will play in implementing adaptation strategies but microfinance itself as the end scope rather than as a means to an end. Czura et al. (2011) also argued that formal and informal credit are coping mechanisms for adverse income shocks in the case of flooding in Northern India. They also observed that most households only relied on informal financing sources, such as family, friends, neighbors, and other relatives, indicating the lack of access to formal financing sources.

Linnerooth-Bayer et al. (2012) reviewed the challenges of post-disaster credit in developing and developed countries. They found that weak financial markets (among service providers) and poverty (associated with vulnerable groups requiring finance in rural areas) are the major factors constraining vulnerable households from coping with post-disaster challenges. Micro-savings, as noted by Linnerooth-Bayer et al. (2012), have significantly increased worldwide (CGAP 2005) and are increasingly channeled through microfinance institutions (MFIs) and banks. However, these savings can be directly affected by disasters, hence resulting in insufficient liquidity to handle shocks (Kull 2006). In less developed countries, savings are also organized through less formal means, such as community-based organizations. These organizations not only pool financial resources, but often set up community grain and seed banks. The poor however spend their limited income primarily on consumption and livelihood investments, with many still lacking access to safe, formal deposit services (Hochrainer et al. 2009; CGAP 2005). Moreover, a sizeable amount of the savings of low-income households are in commitment savings products which might not be accessible in the aftermath of a disaster (Morduch and Armendariz 2010), hence creating a need for post disaster micro-credit.

Post-disaster micro-credit is not without its risks as, increased post-disaster demand can challenge the liquidity of micro-credit organizations and lead to relaxed loan conditions or even debt pardoning. To deal with this problem, development organizations and private investors in Latin America have created a novel intermediary institution, the Emergency Liquidity Facility, which acts as a lender of last resort by providing needed and immediate post-disaster liquidity to MFIs (Linnerooth-Bayer et al. 2012). Governments also borrow to finance their post-disaster liabilities, but generally after they have exploited all available sources from their budgets. In developing countries, funds are often diverted from projects funded by loans from the World Bank and other lending agencies. Whereas this response may be the least costly for a government, it can be disruptive both economically and politically. Most countries require that budget reallocations obtain parliamentary approval, which can delay the appropriation of funding.

Although Linnerooth-Bayer et al. (2012) provided evidence on steps taken in other climes to tackle the issue of loan default, evidence for the southern part of Nigeria also provides a basis for further studies using northern Nigeria as a case study. Using data collected with the aid of questionnaires from a total of 48 microcredit groups and 300 microcredit group members, Enimu et al. (2017) examined the determinants of loan 
repayment among microcredit finance group members in southern part of Nigeria. They found that about 70\% members in microcredit groups are females. Although, such groups enhances access to credit, the high interest rate (up to 40\%) that accompanies such loans makes loan repayment a herculean tasks. The study which employed multiple regression to examine the determinants of loan repayment also found that household size, income and amount of credit received, among other factors, also play a critical part in determining the loan repayment. The paper, therefore suggests that the gender composition of groups organized for reasons of accessing microcredit is important. While this evidence is true for a typical state in the southern part of Nigeria, designing a national policy for enhancing farmers access to credit would require further studies drawing evidence from communities in the northern part of the country as well.

Another reason informing the focus of this paper is due to recent evidence on how drought and desertification have contributed to flaming the conflict between farmers and herders in rural northern communities in northern Nigeria. Many farming communities have been affected by climate change in rural northern Nigeria (see Abraham and Fonta 2018), hence, has made many of the youths, women and children so displaced to be available as recruits for the radical sects such as the Boko Haram and other armed group in the sub region (see Avery 2018). By examining whether the poorest income quintile benefit from programs aimed at increasing their access to financial services in rural northern Nigeria therefore, this paper contributed towards providing field facts that would help redirect the focus of government policy in order to achieve inclusive growth and development.

\section{Theoretical literature}

There are several measures of income distribution, including the median share of income, calculations based on percentile distributions, the Lorenz curve and Gini coefficient, the Robin Hood index, Atkinson index, Thiel's entropy measure, and coefficient of variation (Krol and Miedema 2009). Allison (1978) noted that choosing a standard inequality measure is a choice between the alternative definitions of inequality rather than a choice between the alternative measures of a specific theoretical construct (see Krol and Miedema 2009). Therefore, to measure inequality, we adopt the percentile distribution approach. This method divides the sample population into successive quintiles according to the ascending income levels and then determines the proportion of the income received by each income group using the ratio of incomes received by the poorest $20 \%$, second $20 \%$, third $20 \%$, fourth $20 \%$, and richest $20 \%$. The choice of inequality calculation using the quintile or percentile distribution is based on its strength of using the available data to classify the distribution of income. It can also be used to compute the effectiveness of policies across income quintiles. The choice of this measure follows Krol and Miedema (2009), who argued in favor of using calculations based on quintile, decile, or percentile distributions as robust measures of inequality. The Lorenz curve and Gini coefficient are alternative measures, for which Krol and Miedema (2009) noted they offer both graphical and quantifiable representations of income inequality that can be compared over time and between geographical areas. Although this measure shows the direction and magnitude of income redistribution, it does not indicate where the redistributions are occurring. It also does not allow for within or between income group comparisons. 
In measuring categorical variables, ordered and quantile regressions are comparable. Although Sweeney et al. (2010) show that quantile and ordinal regressions are approximately linked through an inverse relationship, the recovery of the marginal effects of covariates on the estimated unconditional probabilities associated with ordered regression is a major strength. Following Perez-Truglia (2009), let y be the ordered response, taking values $\{0,1, \ldots, J\}$ for some known integer $J$. The latent variable can be written as:

$$
y^{*}=x \beta+e, e \mid x \sim N(0,1)
$$

Let $\alpha_{1}<\alpha_{2}<\ldots<\alpha_{J}$ be unknown cut points (i.e., the threshold parameters), and define

$$
y\left\{\begin{array}{c}
0 \text { if } y^{*} \leq \alpha_{1} \\
1 \text { if } \alpha_{1}<y^{*} \leq \alpha_{2} \\
\vdots \\
J \text { if } y^{*}>\alpha_{J}
\end{array}\right.
$$

Thus, the response probability is computed as stacked in Eq. (3) below:

$$
\begin{aligned}
& P(y=0 \mid x)=P\left(y^{*} \leq \alpha_{1} \mid x\right)=P\left(x \beta+e \leq \alpha_{1} \mid x\right)=\Phi\left(\alpha_{1}-x \beta\right) \\
& P(y=1 \mid x)=P\left(\alpha_{1}<y^{*} \leq \alpha_{2} \mid x\right)=\Phi\left(\alpha_{2}-x \beta\right)-\Phi\left(\alpha_{1}-x \beta\right) \\
& \vdots \\
& P(y=J-1 \mid x)=P\left(\alpha_{J-1}<y^{*} \leq \alpha_{J} \mid x\right)=\Phi\left(\alpha_{J}-x \beta\right)-\Phi\left(\alpha_{J-1}-x \beta\right) \\
& P(y=J \mid x)=P\left(y^{*}>\alpha_{J} \mid x\right)=1-\Phi\left(\alpha_{J}-x \beta\right)
\end{aligned}
$$

Perez-Truglia (2009) noted that parameters $\alpha$ and $\beta$ can be estimated using maximum likelihood. Additionally, while the coefficient of the ordered logit model could have different meaning, qualitative information can be directly extracted from its sign and statistical significance. Furthermore, the marginal effect can also be computed with respect to Xk. In this context, Perez-Truglia (2009) argued that such a process replaces the normal distribution, with the logistic yields in the ordered logit model. The ordered logit model assumes that the distances between each category of the outcome are proportional. Whether this criterion is violated is tested using the Brant test on whether the proportional odds (i.e., parallel lines) assumption holds. The null hypothesis ( $\mathrm{HO})$ is:

H0: The parallel regression assumption has been violated.

Therefore, to reject this hypothesis, the $p$-values associated with each variable should be greater than the 0.05 critical value.

An alternative model for categorical variables is quantile regression. The philosophy behind quantile regression is that rather than estimating a regression by fitting a line based on the mean, the median is often its focus, formalized as

$$
\min _{\xi \in \Re} \sum \rho_{\tau}\left(y_{i}-\xi\right)
$$

This model, which can be estimated using ordinary least squares, defines the unconditional quantiles as an optimizing problem and function $\rho \tau$ (.) is the directional derivative of the objective function with respect to $\xi$. Thus, in a random sample with $\{\mathrm{y}$ y y 1 $2, \ldots, n\}$, solving Eq. 4 yields 


$$
\left.\min _{\mu \in \Re} \sum_{i=1}^{n} y_{i}-\mu\right)^{2}
$$

From Eq. 5, an estimate of the unconditional population mean (i.e., sample mean), EY, is obtained. Replacing the scalar $\mu$ by a parametric function $\mu \beta($, $x$ and solving for it yields Eq. 6:

$$
\min _{\beta \in \Re^{p}} \sum_{i=1}^{n}\left(y_{i}-\mu\left(x_{i}, \beta\right)\right)^{2}
$$

From Eq. 6, an estimate of the conditional expectation function $\mathrm{E}(\mathrm{Y} \mid \mathrm{x})$ is obtained. Replacing the scalar $\xi$ in Eq. 4, the parametric function $\xi\left(x_{i}, \beta\right)$ and $\tau$ are set to $1 / 2$, yielding the estimate of the conditional mean function. To obtain the estimates of the other conditional quantile functions, the conditional quantile functions are replaced by absolute values $\rho \tau$ (.) and solved, leading to the quantile regression in Eq. 7:

$$
\min _{\beta \in \Re^{P}} \sum \rho_{\tau}\left(y_{i}-\xi\left(x_{i}, \beta\right)\right)
$$

According to Koenker and Hallock (2000), quantile regression is also viewed as a natural extension of the classical least squares estimation of conditional mean models. Its special case is the median regression estimator, which minimizes a sum of absolute errors. Therefore, the remaining conditional quantile functions are estimated by minimizing the asymmetrically weighted sum of absolute errors. As an alternative to the ordered logit model, although quantile regression preserves all within category information that may be lost through the categorization of household income into categorical variables to use the ordered logit model, Sweeney et al. (2010) argued that ordered regression has a major advantage: it describes the variation among individuals under the probability of class membership $(j=1,2,3, \ldots, n)$. As Krol and Miedema (2009) argued, using the percentile distribution approach to divide the sample population into successive quintiles by ascending income levels as to determine the proportion of income received by each income group captures direction and magnitude. Harrell (2001) pointed out that, although direct parameter estimates are difficult to interpret in the ordered logit model, post-estimation allows for the recovery of the marginal effects of covariates on unconditional probabilities. This view is also reiterated by Gelman and Pardoe (2007), who emphasized the strength of ordered regression when probabilities are estimated. Nevertheless, Sweeney et al. (2010) also showed that quantile and ordinal regressions are approximately linked through an inverse relationship; thus, interpretations from the two models would provide similar results. To estimate the probabilities for each quintile, the ordered logit model is adapted for this study to achieve its second objective.

\section{Research methodology}

Nigeria constitutes over $50 \%$ of the West African population. Concentrated in the rural area, Nigeria's agricultural sector faces several challenges, including climate shocks, infrastructural, and institutional constraints (see Kwanashie et al. 1998). This has consequences for over $60 \%$ of the nation's 184.264 million people (2015 estimate) that depend on this sector for livelihood. Available statistics show that 39.2 million or $46.3 \%$ of the 
total adult population of 84.7 million Nigerians (with women accounting for 54.4\%) are excluded from financial services. However, around $80.4 \%$ of the financially excluded population resides in rural areas, with over $70 \%$ practicing land use agriculture. Given the impact of climate change on rural livelihood and land use activities, households further suffer from income shocks and are susceptible to falling further below the poverty line.

The studied communities (Fakai in Kebbi state and Rijau in Niger state) both fall in the Sudan savannah region in Northern Nigeria. This region lies within the geographical research focus of the West African Science Service Center on Climate Change and Adapted Land Use (WASCAL). Another factor that influenced the choice of the study areas is poverty. While Niger state has the lowest poverty rate among the communities in the Sudan savannah region of Nigeria (below 34\%), Kebbi state has one of the highest (above 70\%). Drawing samples from both communities therefore eliminates response bias for the questionnaires.

\section{Sample size}

Using a questionnaire instrument, cross sectional household data were randomly collected from two rural communities in the Sudan savannah areas of the North West and North central zones in Nigeria from 320 respondents. The sample size for the study is computed from each community using the formula:

$$
s=\frac{n}{1+\frac{n}{N}},
$$

where $\mathrm{N}$ is the population of each state and $\mathrm{n}$ the population in the studies community. However, $n=\frac{Z^{2}[p(1-p)]}{D^{2}}$ could also be used to compute $\mathrm{n}$. In this case, $\mathrm{p}$ is the proportion of households in poverty, while Z2 and D2 are the confidence level and interval, respectively. Using figures from the 2006 Nigerian census for Fakai, $n=169,111$ and $N=3,256,541$. On the other hand, $\mathrm{n}$ for Rijau is 166,053 and $\mathrm{N}$ is $3,850,249$. Once obtained, $\mathrm{s}$ is divided by 1000 population units. Hence, the sample size for Fakai is 160.8 and for Rijau 159.2, yielding a total of 320 households to sample randomly in each community. The World Bank Group Financial Inclusion (Global Findex) database, launched in 2011 (see Demirguc-Kunt et al. 2015), served as a template for the questionnaire design in this study. The primary data collected and used in this study can be downloaded from WASCAL's Geo portal at https://wascal-dataportal.org/geonetwork/apps/search/.

\section{Analytical framework}

The first objective of the study is to examine the effects of financial inclusive strategies on rural farm households, distributed along income quintiles. Using household income as the dependent variable, respondents' income was classified into five categories: poorest $20 \%$, second $20 \%$, third $20 \%$, fourth $20 \%$, and richest $20 \%$. Thereafter, the ordered logit model, following Perez-Truglia (2009), was used for estimation:

$$
Y_{i}^{*}=\sum_{i=1}^{k} \beta_{k} X_{k i}+\varepsilon_{i}=Z_{i}+\varepsilon_{i}
$$

Equation (8) is a re-specification of Eq. (1), where $\mathrm{X}$ is a vector of $\mathrm{x}$, capturing the gender of the respondents, education, wealth-related variable such as land ownership, 
household size, households in savings clubs, formal credit, crop insurance, and government programs (e.g., distribution of subsidized fertilizers). According to Agresti (2002), since the coefficient on the independent variables in an ordered logit model depends on the densities for $j$ and $j-1(j=2, \ldots, J-1)$ and cannot be determined from the estimate of (8) alone, the partial marginal effects of $\mathrm{X}_{\mathrm{ki}}$ are thus specified as:

$$
\frac{\partial \operatorname{Pr}\left(y_{i}=j \mid X_{i}\right)}{\partial X_{i k}}=\left\{\begin{array}{lc}
-f\left(\delta_{1}-X_{i}^{\prime} \beta\right) \beta_{k} & j=1 \\
\left\{f\left(\delta_{j-1}-X_{i}^{\prime} \beta\right)-f\left(\delta_{j}-X_{i}^{\prime} \beta\right\} \beta_{k}\right. & 1<j \leq J-1 \\
f\left(\delta_{J-1}-X_{i}^{\prime} \beta\right) \beta_{k} & j=J
\end{array}\right.
$$

This ensures that the marginal effects estimates are robust for a system with more than two categorical variables. However, in a logit model with only two categories, the odds-ratio would make for a better interpretation (see Agresti 2002). The cumulative log-likelihood for this estimation is specified as:

$$
\log L=\sum_{i=1}^{n} \sum_{j=1}^{J} d_{i j} \log \left[F\left(\alpha_{j}+X_{i}^{\prime} \beta\right)-F\left(\alpha_{j-1}+X_{i}^{\prime} \beta\right)\right]
$$

The second objective of this paper is to examine whether the poorest income quintile would benefit most from the innovative strategies aimed at increasing access to financial services as a climate change adaptation strategy. It is executed by comparing the probabilities of success from the scenarios that double the uptake in specific financial services from their baseline values. From Eq. 8, the estimated value of $\mathrm{Z}$ and the disturbance term from the assumed logistic distribution can be used to predict the probability of the unobserved variable. Since $Y_{i}^{*}$ falls within various thresholds limits, the general form of the cumulative probability is a respecification of the stacked probabilities in (3), that is:

$$
P\left(Y_{i}>j\right)=\frac{\exp \left(X_{i} \beta-k_{j}\right)}{1+\left[\exp \left(X_{i} \beta-k_{j}\right)\right]}, j=1,2, \ldots, M-1
$$

where $\mathrm{P}(\mathrm{Yi}>\mathrm{j})$ predicts the probability for the policy scenario that scales up the access to the finance, lending to households in savings clubs, crop insurance, and government programs compared to the baseline probability for Eq. (1).

\section{Results and discussion}

\section{Effect of financial access on rural farmers}

The summary statistics from the field data are presented in Table 4 in Appendix. The findings from the estimated ordered logit model (i.e., Eq. 8) are discussed in this section. Following Long and Freese (2006) the Brant robustness test was conducted to verify if the parallel regression assumption was violated. The results showed that the assumption was not violated. Therefore, from the estimated ordered logit model (see Table 1), gender, membership to a savings clubs, access to finance from a formal financial institution, and access to a traditional crop insurance scheme have significant effects on the distribution of rural farm-household income, being significant at the 5\% level. Household size and access to government programs also have a positive effect on household income and are significant at $10 \%$.

The estimated marginal effects in Table 2 show that women are more likely to be in the poorest income quintile, while men are more likely to be in the fourth and richest 20\% quintiles. This finding is also consistent with Enimu et al. (2017) who found that 
Table 1 Estimated Ordered Logit Model

\begin{tabular}{llll}
\hline Variable & Coefficient & Std error & $P$-value \\
\hline Age & 0.068 & 0.0774 & 0.376 \\
Gender & -0.5916 & 0.2078 & 0.004 \\
Education & 0.1262 & 0.1049 & 0.229 \\
House Hold Size & 0.0799 & 0.047 & 0.09 \\
Asset (Land Size) & -0.1433 & 0.1365 & 0.294 \\
Savings Financial Institution & 0.196 & 0.1939 & 0.312 \\
Membership of Community Savings Club & -0.4524 & 0.1701 & 0.008 \\
Borrowing from Financial Institution & -0.3477 & 0.1647 & 0.035 \\
Borrowing from Family and Friend & 0.2072 & 0.2649 & 0.434 \\
Beneficiary to a traditional Crop Insurance scheme & 0.8651 & 0.2534 & 0.001 \\
Benefited from a Government Agricultural Programmes & 0.4437 & 0.2306 & 0.054 \\
Number of Observation & 320 & & \\
LR Chi2 (11) & 33.22 & & \\
Prob > chi2 & 0.0005 & & \\
Pseudo R2 & 0.0323 & & \\
Log likelihood & -498.11 & & \\
\hline Source: Authors Estimation using Field Survey Data (2014) & & & \\
\end{tabular}

Source: Authors Estimation using Field Survey Data (2014) Dependent Variable: Income Quintile

females form a greater proportion of members organized for reasons of attracting microcredit in Delta state of Nigeria, which is located in the southern part of the country. Smaller sized households are also more likely to be in the poorest income quintile than households of larger sizes. This is basically due to the use of family members for farm labor. Ownership of land was not significant from the poorest $20 \%$ to the richest. This reflects the declining value of land in rural areas due to persistent exposure to drought and flash floods, leading to gully erosion and land slide. Those who are in a savings club are more likely to be in the poorest income quintile and those who are

Table 2 Marginal Effects (Ordered Logit Model)

\begin{tabular}{|c|c|c|c|c|c|}
\hline Variable & Poorest 20\% & 2nd $20 \%$ & $3 r d 20 \%$ & 4th $20 \%$ & Richest 20\% \\
\hline Age & $-0.0097(0.377)$ & $-0.0064(0.38)$ & $-0.0002(0.802)$ & $0.0057(0.38)$ & $0.0106(0.377)$ \\
\hline Gender & $0.0824(0.004)$ & $0.05539(0.007)$ & $0.0036(0.59)$ & $-0.047(0.007)$ & $-0.0934(0.005)$ \\
\hline Education & $-0.1791(0.23)$ & $-0.01189(0.238)$ & $-0.00037(0.798)$ & $0.0106(0.236)$ & $0.01955(0.23)$ \\
\hline HH Size & $-0.0113(0.092)$ & $-0.0075(0.10)$ & $-0.00023(0.795)$ & $0.0067(0.101)$ & $0.01238(0.091)$ \\
\hline Asset (Land Size) & $0.0203(0.295)$ & $0.0135(0.299)$ & $0.0004(0.799)$ & $-0.012(0.299)$ & $-0.02219(0.295)$ \\
\hline $\begin{array}{l}\text { Savings Financial } \\
\text { Institution }\end{array}$ & $-0.0278(0.313)$ & $-0.01846(0.317)$ & $-0.00057(0.802)$ & 0.0165 (0.319) & $0.03035(0.313)$ \\
\hline $\begin{array}{l}\text { Membership of } \\
\text { Community Savings Club }\end{array}$ & $0.06418(0.009)$ & $0.04262(0.013)$ & $0.00133(0.795)$ & $-0.03808(0.014)$ & $-0.07005(0.008)$ \\
\hline $\begin{array}{l}\text { Borrowing from } \\
\text { Financial Institution }\end{array}$ & $0.04933(0.037)$ & $0.03276(0.044)$ & $0.00102(0.794)$ & $-0.02927(0.045)$ & $-0.05384(0.035)$ \\
\hline $\begin{array}{l}\text { Borrowing from Family } \\
\text { and Friend }\end{array}$ & $-0.02939(0.435)$ & $-0.0195(0.437)$ & $-0.00006(0.804)$ & $0.0174(0.438)$ & $0.03208(0.435)$ \\
\hline $\begin{array}{l}\text { Ownership of Traditional } \\
\text { Crop Insurance }\end{array}$ & $-0.1227(0.001)$ & $-0.0815(0.002)$ & $-0.0025(0.794)$ & $0.0728(0.003)$ & $0.1339(0.001)$ \\
\hline $\begin{array}{l}\text { Benefited from a } \\
\text { Govt Agric Prgrm }\end{array}$ & $-0.0629(0.056)$ & $-0.0418(0.064)$ & $-0.0013(0.796)$ & $0.0373(0.066)$ & $0.0687(0.055)$ \\
\hline
\end{tabular}

Source: Authors Estimation using Field Survey Data (2014)

Note: Figures in parentheses are $p$-values; Dependent Variable Income Quintile 
not, in the richest income quintile. Additionally, as households move from the poorest to richest income quintile, the likelihood of their participating in community savings club decreases. The marginal effects also show that those in the lowest income quintile would benefit from formal access to credit.

The marginal effect for crop insurance has a negative effect on the poorest income quintile and a positive one on the richest. This implies that traditional crop insurance does not benefit the poorest income quintile. Evidence from the marginal effect of government programs on income quintiles is mixed because the coefficient on the richest income quintile is generally positive but negative for the poorest $20 \%$. Therefore, the tendency is that government agricultural programs on fertilizer distribution, irrigation, and access to improved seedlings could benefit farmers in the richest income quintile most. In summary, from the estimated ordered regression model, the following findings can be deduced:

- The associated probability value of 0.313 in Table 2 shows that having savings with a financial institution does not benefit the poorest income quintile;

- Borrowing from family and friends also does not benefit the poorest income quintile, as the estimated coefficient has a probability value of 0.435 ; and

- Although access to crop insurance is significant at 5\%, the estimated coefficient is negative, implying it does not benefit the poorest income quintile.

\section{Simulation of financial services}

The Nigerian government has continued to implement various agricultural initiatives aimed at extending famers' access to financial services. Determining whether the benefits are evenly distributed across rich and poor farmers or are skewed to a particular quintile is useful. However, an alternative way to achieve this objective is through randomized experiments, as the ex-ante approach could equally provide insight into policy generalization purposes. As such, this section examines whether scaling up the delivery of such services would provide increased access to financial services to the farmers categorized by income quintiles. The predicted probabilities were obtained by estimating Eq. 11. The estimated baseline probability and those obtained from the different scenarios are presented in Table 3 and Fig. 1.

Figure 1 shows that, when access to formal credit is doubled, the highest gain of $12 \%$ would accrue to the poorest income quintile. This implies that access to formal credit has a higher probability of being effective for the poorest income quintile than for the richest

Table 3 Baseline and Predicted Probability Values for Access to Financial Services and Benefit across Quintiles

\begin{tabular}{llllll}
\hline & Baseline & $\begin{array}{l}\text { Doubling Access } \\
\text { to Formal } \\
\text { Finance Scenario }\end{array}$ & $\begin{array}{l}\text { Doubling Access to } \\
\text { Traditional Crop } \\
\text { Insurance Scenario }\end{array}$ & $\begin{array}{l}\text { Doubling Access } \\
\text { to Government } \\
\text { Programmes Scenario }\end{array}$ & $\begin{array}{l}\text { Doubling Credit } \\
\text { to Savings Clubs } \\
\text { Scenario }\end{array}$ \\
\hline Poorest 20\% & 0.1716 & 0.2949 & 0.0429 & 0.0914 & 0.2956 \\
2nd 20\% & 0.2112 & 0.2611 & 0.0754 & 0.14 & 0.2612 \\
3rd 20\% & 0.2227 & 0.2001 & 0.131 & 0.1955 & 0.1998 \\
4th 20\% & 0.2034 & 0.1392 & 0.2288 & 0.2458 & 0.1389 \\
Richest 20\% & 0.1910 & 0.1047 & 0.5219 & 0.3274 & 0.1044 \\
\hline
\end{tabular}

Source: Authors Estimation using Field Survey Data (2014)

Note: Gain by Income Quintile for each Scenario is the probability from the given scenario minus baseline probability 


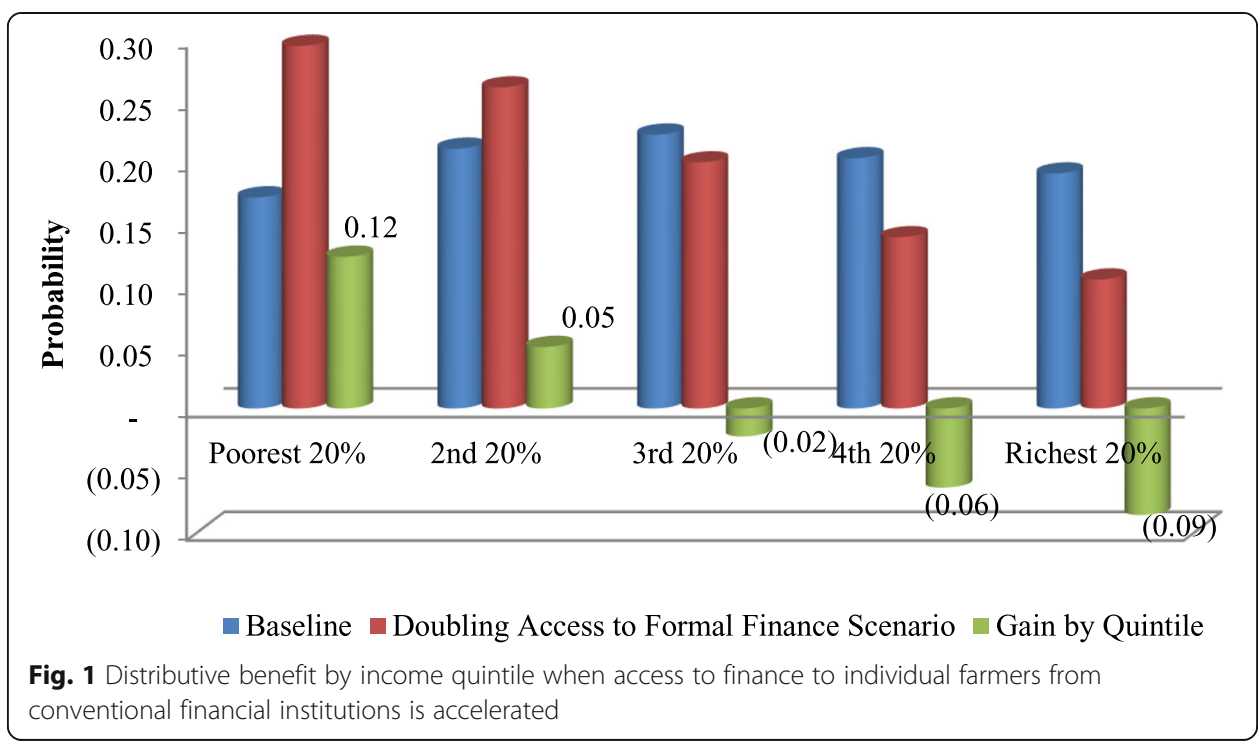

$20 \%$ farmers. The policy implication is that existing MFIs have the potential to bridge the access to the finance needed by poor farmers to stay in business and adapt to shocks. However, they are not taking their products to those that need them the most. This argument is consistent with Dabla-Norris et al. (2013), Collier (2013), and IMF (2014), who argue that access to financial services could strengthen the resilience of households to climate change.

For crop insurance, under a policy scenario that seeks to continue providing farmers with access to traditional crop insurance, there is a higher chance that the richest income quintile would benefit most. Figure 2 shows that the gain attributed to the richest income quintile from such a policy is $33 \%$ for the richest $20 \%$ but would be reduced by $13 \%$ for the poorest $20 \%$. The evidence that crop insurance benefits the richest income quintile of farmers but does not benefit poor- to middle-income farmers is consistent with Hess et al. (2002), who argued that traditional crop insurance does not benefit poor and vulnerable groups due to its expensive structure.

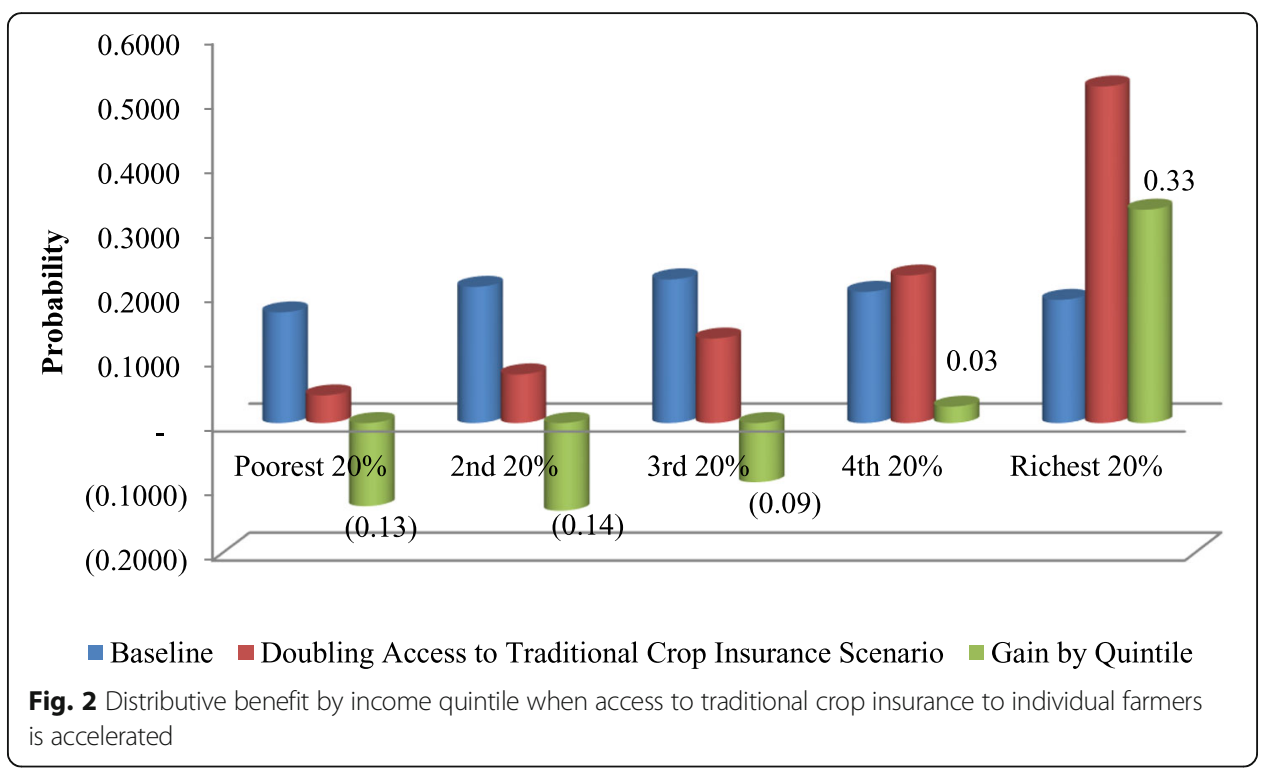


The scenario under which lending to rural households is doubled using savings clubs is presented in Fig. 3. It shows an equal percentage gain for the poorest quintile of $12 \%$ which is the same with the gain from doubling access to lending from formal financial institutions. The competing gain to the poorest income quintile farmers from scaling up access to formal credit and lending to savings clubs also suggests that organizations play a critical role for such outcomes. Such an organization, as Sorensen (2000) argued, provides a platform to improve farmers productivity, as well as their access to credit.

This finding is also consistent with Uphoff (1998), who argued that horizontal linkages among base-level organizations are critical for improving outcomes, provided they are well organized and households act in the interest of the group. Such an organization is also consistently needed for transiting to rotational and accumulating savings associations or accumulating credit associations, which according to Bouman (1995), are critical for assisting financial self-help groups in developing countries. The use of farm households organized as groups is consistent with Sorensen (2000), who argued it would be beneficial for mutual risk-sharing. The scenario that doubles access to government programs (see Fig. 4) showed that the greatest benefit would accrue to the richest farmers. Government programs, mostly dealing with the provision of subsidized fertilizers, irrigation programs, and access to improved seedlings in northern Nigeria, clearly do not benefit poor farmers.

The policy scenario analysis on the effectiveness of government programs shows that the gain from scaling up government programs in the agricultural sector to the richest $20 \%$ is $14 \%$, while the poorest income quintile recorded the greatest loss of $8 \%$. The second poorest income quintile recorded a loss of $7 \%$ and the middle income farmers a $3 \%$ loss, while the fourth and richest income quintile recorded a $4 \%$ gain. These findings do not agree with the Farauta et al. (2011), who found that government programs are effective in helping households build resilience to agricultural shocks. Following Zeller and Sharma (2002), who pointed out the need for identifying households who may have chosen not to borrow even when they had access to credit and others who wanted to borrow but had no access, we asked if the respondents had access to finance but choose not to borrow. The responses show that $95.94 \%$ of those who needed finance were not able to borrow (see Fig. 5).

When asked the purpose for which the credit was sought, the distribution of responses (see Fig. 6) showed that, of the 320 respondents, most households needed

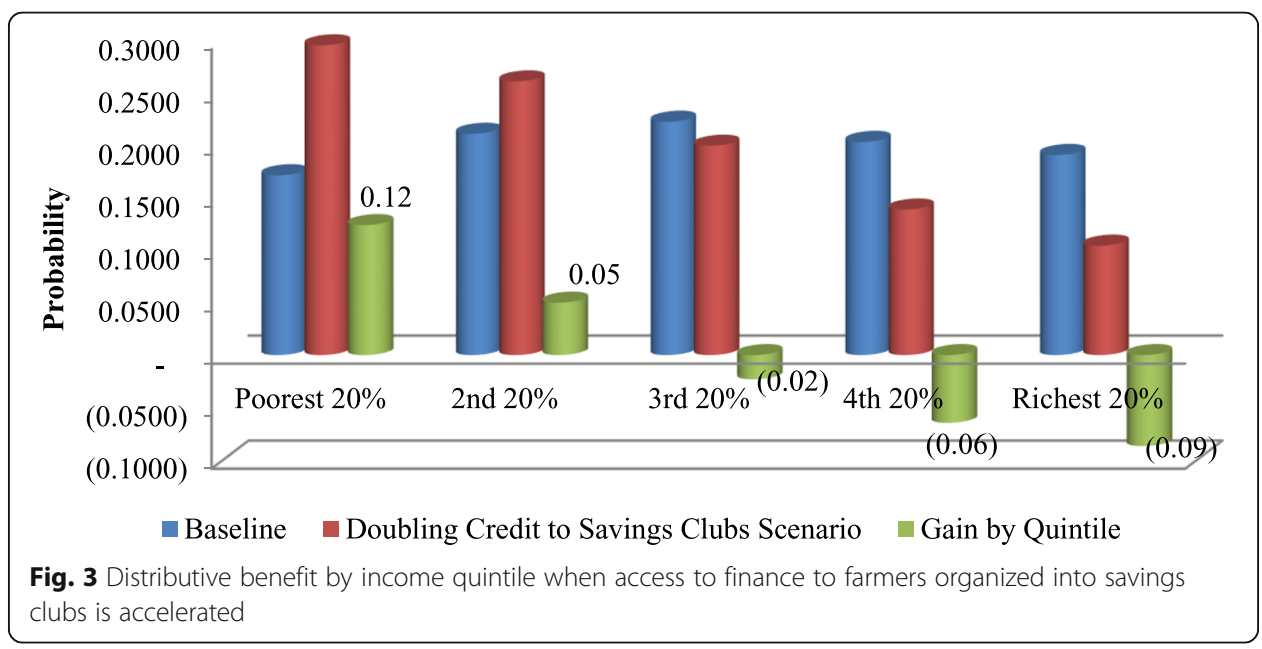




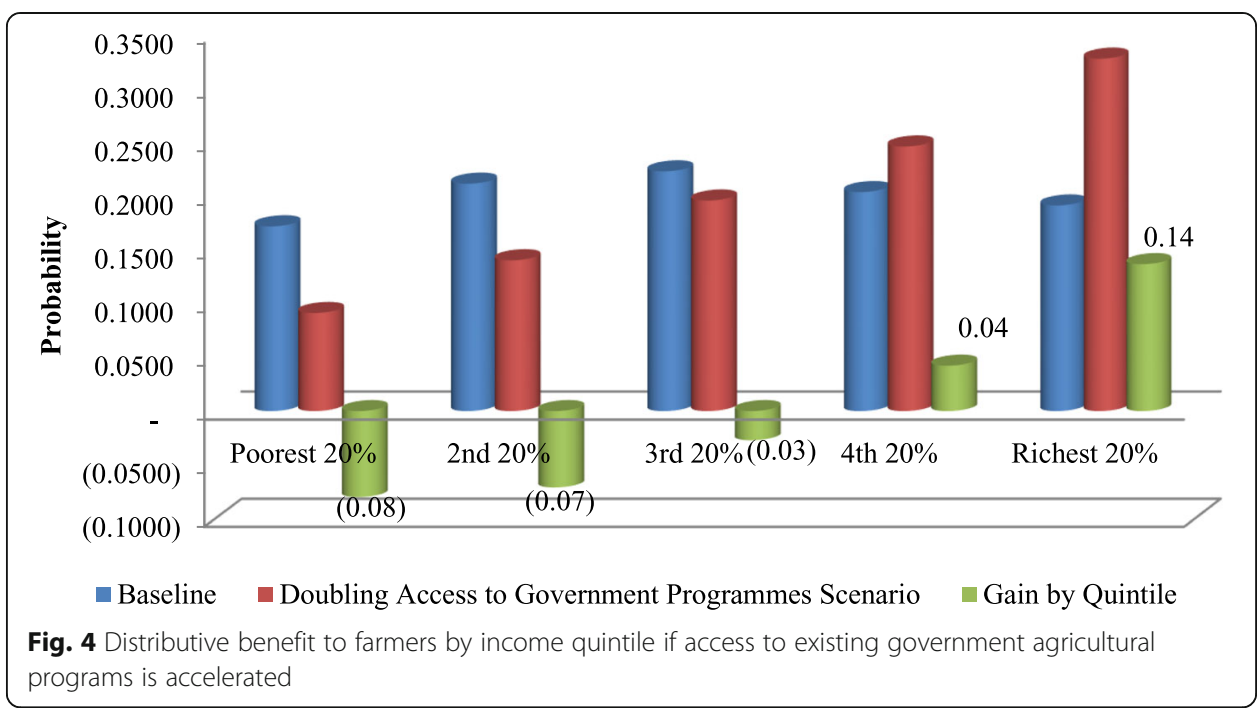

credit to purchase fertilizers (23.12\%), dig borehole for water/irrigation purposes (19.06\%), and buy improved seedlings (16.88\%). As previously mentioned, past government programs in Nigeria have focused tremendously on improving access to fertilizers, irrigation, and improved seedlings. However, the high proportion of farmers needing access to credit for these same reasons indicates that government programs in this aspect may not be reaching those that need them most.

In summary, the findings indicate that doubling access to credit for the farmers organized around a savings club or through formal financial institutions would benefit the poorest income quintile most. This result is consistent with those obtained from the estimated marginal effect. Therefore, based on the statistical significance of the probability value in the marginal effect model of $5 \%$, the hypothesis that the poorest income quintile benefits most from financial inclusive services that enhance their access to credit using formal financial institutions and savings clubs grouping rural farm households, hence increasing their adaptive capacity to the negative effects of climate change, is supported.

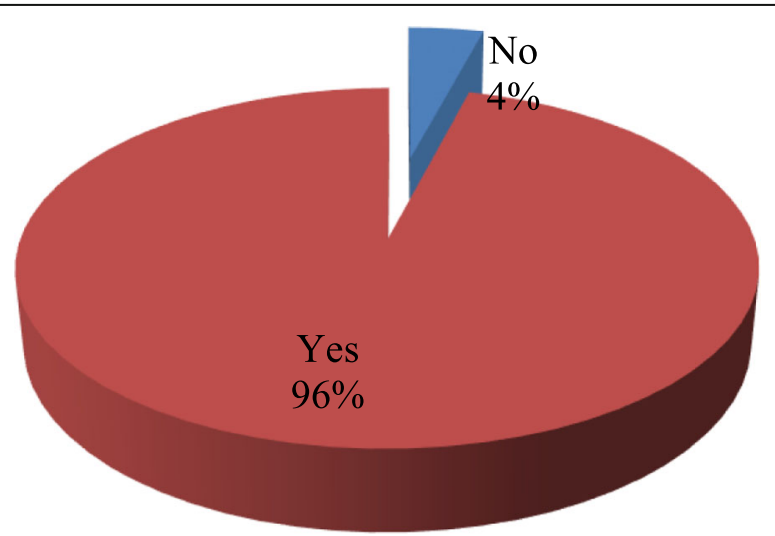

Fig. 5 Proportion of Respondents who needed finance but had No access. Source: Abraham and Fonta (2018) 


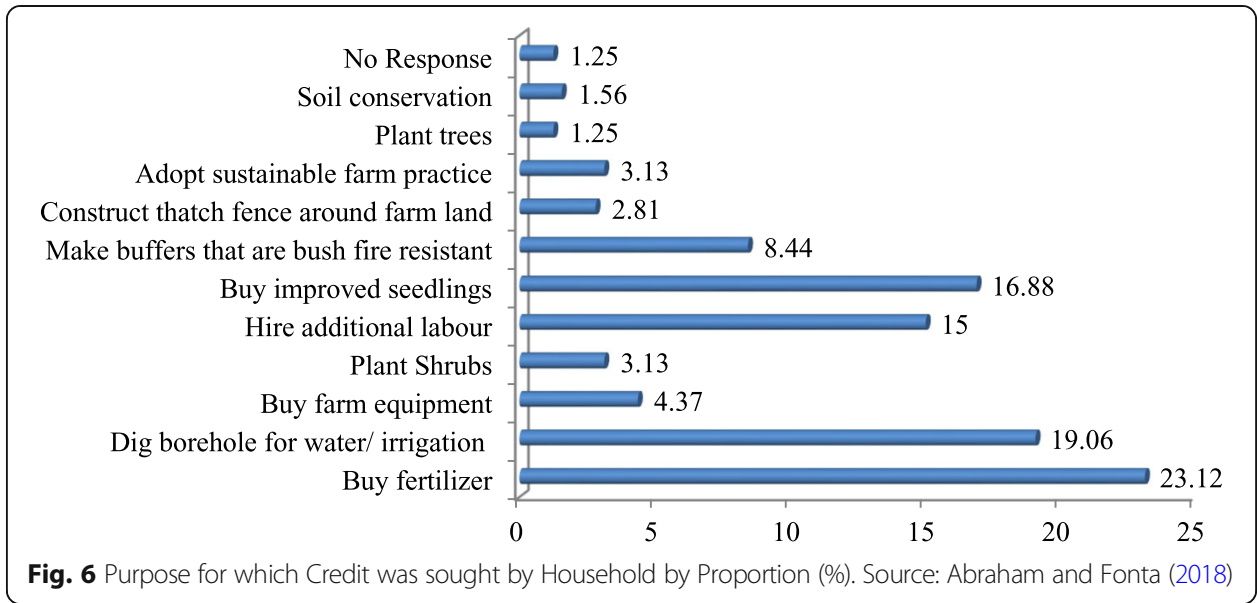

\section{Conclusions and recommendations}

Recognizing the gap in the literature in examining the effects of financial resources and development outcomes at the household level, this study examines the effects of financial access and also whether the poorest income quintile would benefit most from programs aimed at increasing their access to financial services as a climate change adaptation strategy. The findings show that, while access to formal credit has a positive effect on farmers in the poorest income quintile, membership of savings clubs by farmers would equally deliver finance access to farmers in the poorest income quintile. Moreover, traditional crop insurance was found to mostly benefit rich farmers. Therefore, investments in alternative insurance products that would help SHFs cope with the increased uncertainty in the rainfall pattern and increased drought would be important. Furthermore, despite the government's efforts to improve the agricultural value chain in Nigeria through irrigation, fertilizer delivery, and improved seedling access for farmers, the SHFs considered in this study indicated they still require finance to purchase most of these items. This suggests that the programs proposed to help rural farm households cope with agricultural shocks, do not benefit the farmers in the poorest income quintile. The government should therefore not relent in its effort to strengthen the agricultural value chain in Nigeria.

To move toward the eradication of poverty for all under a post-2015 sustainable development framework, looking into how rural farm households are organized in developing countries and designing financially inclusive products that would be consistent with their values and community life are important measures. The benefits for the poorest income quintile from formal financial institutions and community savings clubs in our scenario analysis suggest there is a need for the CBN and central banks in other developing countries to continue initiating reforms that will target poor, excluded, and vulnerable farm households with access to finance as to: (1) enhance access to financial resources, (2) enable farmers to build resilience to climate change, (3) keep rural households in the farming business, and (4) contribute to actualizing the decisions reached in the UNFCCC Conference of Parties (COP) 21, Section 55, Subsection (b), paragraph (ii), which seek to identify initiatives that would deliver better microfinance to poor farmers as a climate change adaptation strategy. 


\title{
Appendix
}

Table 4 Description of Variables

\begin{tabular}{|c|c|c|}
\hline Variables Name & Description & Measurement Scale \\
\hline Gender & Gender of Respondent & $\begin{array}{l}\text { Male }=44.69 \% \\
\text { Female }=55.31 \%\end{array}$ \\
\hline Edu & Educational Qualification of Respondent & $\begin{array}{l}\text { Quranic/primary }=41.56 \% \text {, } \\
\text { Secondary/ post-secondary }=58.44 \%\end{array}$ \\
\hline HH size & Household Size & $\begin{array}{l}\text { Max }=12 \\
\text { Minimum }=1 \\
\text { Mean }=5.59\end{array}$ \\
\hline $\begin{array}{l}\text { Family Total } \\
\text { Income (In a year) }\end{array}$ & Family Total Income (In Nigerian Naira) & $\begin{array}{l}\text { Max }=360,000 \\
\text { Minimum }=13,000 \\
\text { Mean }=91,372\end{array}$ \\
\hline$\%$ of Farm Income & & $77 \%$ \\
\hline$\%$ of Off-Farm Income & & $23 \%$ \\
\hline q13aSaveFI & Savings with Financial Institution & $\begin{array}{l}\text { Yes }=20.31 \% \\
\text { No }=79.69 \%\end{array}$ \\
\hline q13bSaveSC & Membership of a Community Savings Clubs & $\begin{array}{l}\text { Yes }=66.56 \% \\
\mathrm{No}=33.44 \%\end{array}$ \\
\hline q14aBFI & $\begin{array}{l}\text { Access to finance (borrowing) from Financial } \\
\text { Institution }\end{array}$ & $\begin{array}{l}\text { Yes }=80 \% \\
\text { No }=20 \%\end{array}$ \\
\hline q14cBFnF & $\begin{array}{l}\text { Access to finance (borrowing) from Family and } \\
\text { Friends }\end{array}$ & $\begin{array}{l}\text { Yes }=87.5 \% \\
\text { No }=12.5 \%\end{array}$ \\
\hline InsureAgric & Traditional Crop Insurance & $\begin{array}{l}\text { Yes }=22.81 \% \\
\text { No }=77.19 \%\end{array}$ \\
\hline GovtAgPrgm & $\begin{array}{l}\text { Benefit to a Government Agricultural Programme } \\
\text { (fertilizers, irrigation, improved seedlings, efforts } \\
\text { to mechanize farming) }\end{array}$ & $\begin{array}{l}\text { Yes }=36.56 \% \\
\text { No }=63.44 \%\end{array}$ \\
\hline $\begin{array}{l}\text { Dependent Variable } \\
\text { (Income Quintile) }\end{array}$ & $\begin{array}{l}\text { Poorest } 20 \% \text {, Second } 20 \% \text {, Middle } 20 \% \text {, } \\
\text { Fourth } 20 \% \text {, \& Richest } 20 \%\end{array}$ & $\begin{array}{l}\text { Poorest } 20 \%=18.44 \% \\
\text { Second } 20 \%=20 \% \\
\text { Middle } 20 \%=20.63 \% \\
\text { Fourth } 20 \%=20 \%, \& \\
\text { Richest } 20 \%=20.94 \%\end{array}$ \\
\hline
\end{tabular}

Source: Abraham and Fonta (2018)

\begin{abstract}
Abbreviations
AFI: Alliance for Financial Inclusion; ASCRAs: Accumulating Saving and Credit Associations; BMBF: German Federal Ministry of Education; BNRCC: Building Nigeria's Response on Climate Change; CBOs: Community-based organizations; CGAP: The Consultative Group to Assist the Poor; CH4: Methane (biogeochemical effects); CO2: Carbon dioxide (biogeochemical effects); COP: The UNFCCC Conference of Parties; ELF: Emergency Liquidity Facility; G20: Group of Twenty (an International forum for the governments and central bank governors from 20 major economies); IFIs: International Financial Institutions; IFPRI: The International Food Policy Research Institute; IPCC: The Intergovernmental Panel on Climate Change; MFIs: Microfinance institutions; NASPA-CCN: National Adaptation Strategy and Plan of Action on Climate Change; ODA: Oversee Development Assistance; OLM: Ordered logit model; OLS: Ordinary Least Square Regression; ROSCAs: Rotational and accumulating saving and credit associations; SMEs: Small and medium enterprises; UNFCCC: The United Nations Framework Convention on Climate Change; Vision 20:2020: Nigeria's Vision to rank among the world's top 20 economies by the year 2020; WASCAL: West African Science Service Center on Climate Change and Adapted Land Use
\end{abstract}

\section{Acknowledgements}

The Author appreciates the German Federal Ministry of Education (BMBF) for funding this research through the WASCAL Graduate Programme on Climate Change Economics and the Universite Cheikh Anta Diop, Dakar - Senegal, within 2013-2016. As such, the author appreciates Prof. A. Aly Mbaye (mbayealy93@yahoo.fr) the Director of the WASCAL programme at the FASEG, Universite Cheikh Anta Diop for his contributions as the thesis advisor and Dr. William M. Fonta (fontawilliam@gmail.com) for his contribution when the author visited at the WASCAL Competence Centre at Ouagadougou, Burkina Faso.

More so, deep appreciation is also extended to MFW4A (Making Finance Work for Africa) and the ADA for useful comments on earlier draft of findings in this paper published by MFW4A and the ADA as a Working paper of the 2015 African Microfinance Week that helped shaped this version. 


\section{Funding}

This paper benefits from the Graduate Research Programme in Climate Change Economics fund provided by the German Federal Ministry of Education (BMBF) in collaboration with the Zentrum für Entwicklungsforschung (ZEF)/ Centre for Development Research, Department for Economic and Technological, Universität Bonn, Bonn - Germany under the West African Science Service Center on Climate Change and Adapted Land Use (WASCAL) hosted at the Universite Cheikh Anta Diop de Dakar, Senegal.

In 2015, Terfa W. Abraham was one of the recipient of the MFW4A (Making Finance Work for Africa) Research Paper prize for his paper titled, "Financial Innovation and Poverty Reduction: Evidence from Northern Nigeria". The paper was presented at the Research Meets Africa Conference during the African Microfinance Week (i.e. Semaine Africaine de la Microfinance - SAM): a University Meets Microfinance (UMM) workshop organized in collaboration with ADA (Appui au Développement Autonome) and Positive Planet during the African Microfinance Week on June 9, 2015. The MFW4A award, therefore provided additional funds that helped advance this research paper.

\section{Availability of data and materials}

The primary data collected and used for this study was funded under the German Federal Ministry of Education (BMBF) Funds for Climate Change Economics under the WASCAL (West African Science Service Centre on Climate Change and Adapted Land Use) Graduate Research Programme for 2013-2016 at the Universite Cheikh Anta Diop, de Dakar - Senegal. The data set is hosted on the WASCAL Geo portal available on the link: https:/wascal-dataportal.org/geonetwork/apps/search/

Declaration

I declare that the research article titled, 'Estimating the Effects of Financial Access on Poor Farmers in Rural Northern Nigeria', is an article from my research work funded by the German Federal Ministry of Education (BMBF) through the Climate Change Economics doctoral research programme under the WASCAL (West African Science Service Centre on Climate Change and Adapted Land Use) initiative.

\section{Authors' contributions}

This paper is an extract from the Ph.D thesis of TWA at the Universite Cheikh Anta Diop de Dakar, Senegal, funded under the BMBF/WASCAL Graduate Research Programme in Climate Change Economics. As such, there are no contributing authors this paper. The author read and approved the final manuscript.

\section{Competing interests}

Though this research paper is extracted from the PhD thesis of the author which was funded by the German Federal Ministry of Education (BMBF) through the WASCAL graduate programme at Universite Cheikh Anta Diop, Dakar Senegal, an earlier draft of this paper also benefited from the research paper prize awarded to the author by the Making Finance Work for Africa (MFW4A) during the University Meets Microfinance (UMM) conference in Dakar, 2015. The earlier draft was first presented at the Research Meets Africa, a UMM workshop organized in collaboration with Appui au Développement Autonome (ADA) and Positive Planet during the African Microfinance Week, on June 29, 2015, and later published as a MFW4A Working Paper Series by the Making Finance Work for Africa (MFW4A) Secretariat. Again the author appreciates his thesis examiner at Universite Cheikh Anta Diop, de Dakar, Dr. William M. Fonta, for the mentorship provided since the earlier draft that has led to the completion of this paper.

\section{Publisher's Note}

Springer Nature remains neutral with regard to jurisdictional claims in published maps and institutional affiliations.

Received: 8 September 2017 Accepted: 12 October 2018

Published online: 29 October 2018

\section{References}

Abraham TW, Fonta WM (2018) Climate change and financing adaptation by farmers in northern Nigeria. Financ Innov 4(11): $1-17$

Adesina A (2012) Transforming agriculture to grow Nigeria's economy. Convocation lecture delivered at the Obafemi Awolowo University, lle Ife, December 13th

Agresti A (2002) Categorical data analysis, 2nd edn. Wiley, New York

Akinlo AE (2014) Policy choices and challenges in expanding access to finance for growth in rural Nigeria. Eur J Sustain Dev $3(1): 135-144$

Allison PD (1978) Measures of inequality. Am Sociol Rev 43(6):865-880

Anyanwu JC (1997) Structure of the Nigerian economy: 1960-1997. Joanee Publications, Onitsha

Avery JS (2018) The refugee crisis: chapter 8 in population and the environment, page 213-219. Available on http://eacpe. org/app/wp-content/uploads/2018/07/Population-And-The-Environment-by-John-Scales-Avery.pdf

Boko M, Niang I, Nyong A, Vogel C, Githeko A, Medany M, Osman-Elasha B, Tabo R, Yanda P (2007) In: Parry ML, Canziani OF, Palutikof JP, van der Linden PJ, Hanson CE (eds) Africa climate change: impacts, adaptation and vulnerability'. Contribution of working group II to the fourth assessment report of the intergovernmental panel on climate change. Cambridge University Press, Cambridge, pp 433-467

Bouman FJA (1995) Rotating and accumulating savings and credit associations: a development perspective. World Dev 23(3): $371-384$

CBN (2016) Anchor borrowers programme guideline. A publication of the development finance department of the Central Bank of Nigeria (CBN)

CGAP (2005) Protecting microfinance borrowers. Consultative Group to Assist the Poor (CGAP) Publication, Washington D.C

Collier BL (2013) Financial inclusion and natural disasters. Doctoral Dissertation, University of Kentucky, Department of Agricultural Economics, (Dissertation Supervisors: Jerry R. Skees, Michael Reed and Mario Miranda), Lexington 
Czura C, Karlan D, Mullainathan S (2011) Does flexibility in microfinance pay off? Evidence from a randomized evaluation in rural India. In: Goethe University Frankfurt, paper presented at the second European research conference on microfinance (Groningen)

Dabla-Norris E, Ho G, Kyobe A, Tchaidez R (2013) Anchoring growth: the importance of productivity-enhancing reforms in emerging markets and developing economies. IMF staff discussion note 13/08. International Monetary Fund, Washington

Demirguc-Kunt A, Klapper L, Singer D, Van Oudheusden P (2015) The global Findex database 2014: measuring financial inclusion around the world' World Bank Group, policy research working paper 7255

EFInA (2016) Survey report of enhancing financial innovation \& access (EFInA). Available on http://www.efina.org.ng/assets/ A2F/2016/Key-Findings-A2F-2016.pdf

Enimu S, Eyo EO, Ajah EA (2017) Determinants of loan repayment among agricultural microcredit finance group members in Delta state, Nigeria. Financ Innov 3(21):1-12

Farauta BK, Idrisa YL, Egbule CL, Agu VC (2011) Farmers' perceptions of climate change and adaptation strategies in northern Nigeria: an empirical assessment. African technology policy studies network research paper no. 15

Fonta WM, Onyukwu OE, Nwosu EO (2011) International remittance inflows and household welfare: empirical evidence from Nigeria. Research Journal of Finance and Accounting, 2(3): 140-149

Forcella D (2013) Microfinance and adaptation to climate change. 10th University Meets Microfinance (UMM) Workshop, Frankfurt

G20 (2011) The G20 global partnership on financial inclusion. World Bank Group Donor Forum, May $18^{\text {th }}$, Paris

Gelman A, Pardoe I (2007) Average predictive comparisons for models with nonlinearity, interactions, and variance components. Sociol Methodol 37(1):23-51

Harrell F (2001) Regression modeling strategies: with applications to linear models, logistic regression, and survival analysisr. New York: Springer-Verlag

Haughton J, Khandker SR (2009) Handbook on poverty and inequality. World Bank, Washington D.C

Hess U, Richter K, Stoppa A (2002) Weather risk management for agriculture and agribusiness in developing countries. In: Dischel RS (ed) Climate risk and the weather market: financial risk management with weather hedges. Risk Books, London

Hochrainer S, Mechler R, Pflug G (2009) Climate change and financial adaptation in Africa. Investigating the impact of climate change on the robustness of index-based microinsurance in Malawi. Mitig Adapt Strat Glob Change 14(3):231-250

IMF (2014) Sub Saharan Africa regional economic outlook: fostering durable and inclusive growth' International Monetary Fund (IMF) publication (April) world economic and financial surveys

IPCC (2007) In: Solomon S, Qin D, Manning M, Chen Z, Marquis M, Averyt KB, Tignor M, Miller HL (eds) Climate change 2007: the physical science basis. Contribution of working group I to the fourth assessment report of the intergovernmental panel on climate change (IPCC). Cambridge University Press, Cambridge and New York, p 996

IPCC (2012) In: Field CB, Barros V, Stocker TF, Qin D, Dokken DJ, Ebi KL (eds) Managing the risks of extreme events and disasters to advance climate change adaptation. A special report of working groups I and II of the intergovernmental panel on climate change (IPCC)

Koenker R, Hallock KF (2000) Quantile regression: an introduction. Journal of economic perspectives 'symposium on econometric tools'

Krol A, Miedema JM (2009) Measuring income inequality: an exploratory review. A publication of region of Waterloo public no. 431158

Kull D (2006) Financial services for disaster risk management for the poor. In: Chakrabarti PGD, Bhat MR (eds) Micro-finance and disaster risk reduction. National Institute of Disaster Management in association with Knowledge World, Delhi, pp 39-64

Kwanashie M, Ajilima I, Garba AG (1998) The Nigerian economy: response of agriculture to adjustment policies. African economic research consortium (AERC) research paper 78 (march)

Linnerooth-Bayer J, Hochreiner-Stigler S, Mechler R (2012) Mechanisms for financing the costs of disasters. Report produced for the UK government Office of Science, foresight project 'reducing risks of future disasters: priorities for decision makers

Long JS, Freese J (2006) Regression models for categorical dependent variables using Stata, 2nd edn. Stata Press, College Station

MeheRette E (2009) Innovations in insuring the poor: providing weather index and indemnity insurance in Ethiopia. International food policy research institute (IFPRI) 2020 vision for food, agriculture, and the environment, focus 17 brief 8 (December)

Morduch B, Armendariz J (2010) The economics of microfinance. MIT Press, Boston

NILDS and PASGR (2018), 'Gauging the Federal Government of Nigeria commitment to supporting agriculture transformation for employment creation' National Institute for legislative and democratic studies (NILDS) and Partnership for African Social \& governance research (PASGR) Utafiti sera policy brief no. 2

Perez-Truglia R (2009) Applied econometrics using STAT. Harvard University Press, Harvard

Ravallion M, Chen S (2001) Measuring pro-poor growth. Policy research working paper no. 2666. World Bank, Washington, DC

Sanfo S, Gérard F (2012) Public policies for rural poverty alleviation: the case of agricultural households in the plateau central area of Burkina Faso. Agr Syst (Elsevier) 110:1-9

Schneider K, Gugerty MK (2011) Agricultural productivity and poverty reduction: linkages and pathways. Evans School Rev 1(1):56-74

Siegel PB, Alwang J (2005) Poverty reducing potential of smallholder agriculture in Zambia: opportunities and constraints. Africa region working paper series, number 85 . The World Bank, Washington, D.C

Sorensen C (2000) Social capital and rural development: a discussion of issues. World Bank social capital initiative working paper no. 10

Sweeney S, Davenport F, Grace K (2010) Combining insights from quantile and ordinal regression: child malnutrition in Guatemala. Econ Hum Biol. 1-29. http://citeseerx.ist.psu.edu/viewdoc/download?doi=10.1.1.104.9767\&rep=rep1\&type=pdf

Uphoff N (1998) Reasons for success. Kumarian Press, West Hartford

Vargas-Hill R, Torrero M (2009) Innovations in insuring the poor. In: 2020 focus briefs, no. 17, IFPRI, Washington DC

World Bank (2008) Rural finance in Nigeria: integrating new approaches' a World Bank report no. 44741-NG

World Bank (2012) 'Financial innovations for social and climate resilience: Establishing an evidence base' Social Resilience \& Climate Change study, World Bank Publication

Zeller M, Sharma M (2002) Access to and demand for financial services by the rural poor: a multicountry synthesis. In: Zeller M, Meyer RL (eds) The triangle of microfinance: financial sustainability, outreach, and impact. International Food Policy Research Institute (IFPRI) Publication, pp 19-45 